\title{
Extraterritorial military action
}

Vito Todeschini

\section{Introduction}

Extraterritorial human rights obligations (ETOs) arise whenever states undertake military action outside national territory. A preliminary question is when ETOs apply in relation to military operations. First, states bear ETOs when exercising 'power or effective control' over a person (Human Rights Committee (HRC) 2004a, para. 10), typically in cases of deprivation of liberty. Second, ETOs arise when a state exercises effective control over foreign territory, including in situations of occupation (HRC 2018, para. 63). Third, states have ETOs vis-à-vis any individual whose rights are 'impacted by its military or other activities in a direct and reasonably foreseeable manner' (ibid), e.g., when states carry out airstrikes without 'boots on the ground'. The Maastricht Principles on Extraterritorial Obligations of States in the Area of Economic, Social and Cultural Rights (Maastricht Principles) incorporate these principles, recognizing that ETOs arise in connection to the exercise of effective control over a person or territory, or when state action has 'foreseeable effects on the enjoyment' of economic, social and cultural (ESC) rights (Principles 9 and 18).

A corollary question is which ETOs states are bound by when undertaking extraterritorial military action. Under human rights law, states generally bear three types of obligations (Committee on Economic, Social and Cultural Rights (CESCR) 2000, para. 33). The obligation to respect requires states to 'refrain from interfering directly or indirectly with the enjoyment' of human rights. The obligation to protect prescribes that states must 'take measures that prevent third parties from interfering' with human rights. The obligation to fulfil imposes on states a duty to 'adopt appropriate legislative, administrative, budgetary, judicial, promotional and other measures towards the full realization' of human rights. The obligation to fulfil in turn encompasses the obligations to facilitate, provide and promote (ibid). While within national territory states bear all three obligations, in extraterritorial contexts these various obligations arise depending on the type and degree of control states exercise. As it will be shown, whereas the obligation to respect applies in all circumstances, given that states are always in a position to refrain from interfering with human rights, the obligations to protect and fulfil will apply only when a state exercises effective control over a person or territory. The latter obligations, in fact, require that a threshold criterion be met in order to be triggered (Milanovic 2011, pp. 209 ff.). 
At the same time, it is relevant noting that, while the analysis will attempt to identify which of these obligations apply in the various scenarios considered below, the application of and boundaries between such obligations is not rigid.

Section 2 will look at the ETOs arising in connection with deprivation of liberty. Section 3 will focus on the obligations states bear when exercising effective control over territory. Section 4 will then consider the ETOs deriving from use of force against individuals, and Section 5 will briefly delve into what ETOs require when states participate in UN-mandated peace operations. Section 6 will offer an appraisal of the relevance of the Maastricht Principles in the area of extraterritorial military action. Section 7 will conclude by highlighting some of the open questions regarding the applicability of ETOs in relation to extraterritorial military action.

\section{Deprivation of liberty and control over persons}

Deprivation of liberty constitutes an exercise of 'physical power and control' (European Court of Human Rights (ECtHR) 2011b, para. 136) or 'effective control' (HRC 2014a, para. 63) that brings an individual under a state's jurisdiction, triggering relevant ETOs. This is the so-called 'personal model' of jurisdiction (Milanovic 2011, pp. $173 \mathrm{ff}$.), according to which a state has an obligation to secure human rights due to the exercise of control over persons. Whether a deprivation of liberty is authorized or lawful is immaterial: exercise of control per se establishes a jurisdictional link between a state and an individual, 'regardless of the circumstances in which such power or effective control was obtained' (HRC 2004a, para. 10).

When exercising de jure or de facto effective control over a person, states have an obligation to ensure the protection of all the human rights that are relevant to the situation of that individual (ECtHR 2011b, para. 136). Because persons deprived of their liberty are under the complete control of the detaining state, the latter must respect, protect and fulfil the whole range of human rights international law affords to them. This entails, first, respecting their right to life and to be free from torture and other cruel, inhuman or degrading treatment or punishment (ill-treatment), as well as their right to personal liberty and security, including all ensuing procedural guarantees (HRC 2014a, para. 63; 2018, para. 63). A state also has the obligation to protect an individual from violence and other threats to their life while in detention (African Commission on Human and Peoples' Rights (AComHPR) 2015, para. 36). With regard to ESC rights, the Maastricht Principles provide that '[a] State exercising effective control over persons outside its national territory must respect, protect and fulfil [the ESC] rights of those persons' (Principle 18). For instance, a state will have the obligation to fulfil the rights relating to adequate food, water, clothing, housing conditions and healthcare (International Covenant on Economic, Social and Cultural Rights (ICESCR), arts. 11-12; UN Standard Minimum Rules for the Treatment of Prisoners, rules 12-35). Whenever a state is unable to fully provide the detention standards required under international law, it nevertheless must guarantee, 'at the very least, minimum essential levels of each of the [ESC] rights' in line with the minimum core obligations entrenched in the ICESCR (CESCR 1990, para. 10).

It is to be noted that, in situations of armed conflict, the rules of international humanitarian law (IHL) governing detention may lead to frictions with a state's applicable ETOs. In particular, IHL allows for the internment of individuals (Geneva Convention (GC) III, arts. 21 and 118; GC IV, arts. 42-43, 78 and 132), ${ }^{1}$ namely deprivation of liberty based on security grounds rather than on the alleged or actual commission of a crime. While such form of detention is generally not compliant with human rights law (ECtHR 2011a, para. 100), as it amounts to prohibited 'arbitrary' detention, the HRC has affirmed that '[s] ecurity detention authorized and regulated by and complying with international humanitarian law in principle is not arbitrary' (2014a, 
para. 64; also ECtHR 2014a, paras. 104-105). In this sense, the standard of 'arbitrariness' is interpreted in light of the rules of IHL, which allow for security detention, rather than human rights law (Inter-American Commission on Human Rights (IAComHR) 1999, para. 42). ${ }^{2}$ As a result, carrying out internment in line with IHL does not, in principle, infringe upon human rights law; in contrast, internment that violates IHL implies a corresponding breach of the prohibition of arbitrary detention.

Furthermore, the review of detention under IHL does not necessarily meet the standards prescribed by human rights law. For this reason, the ECtHR has affirmed that the relevant review body, which under IHL may or may not be of a judicial nature, should provide 'sufficient guarantees of impartiality and fair procedure'; furthermore, 'the first review should take place shortly after the person is taken into detention, with subsequent reviews at frequent intervals' (2014a, para. 106). Hence, the ECtHR requires that internment in international armed conflict be compliant with certain essential protections surrounding the right to liberty. On the other hand, IHL also prescribes that interned persons be treated humanely, be protected from torture and ill-treatment and be provided with conditions of detention that safeguard their life and preserve their health (inter alia, GC III, arts. 3, 13 and 15; Additional Protocol I (AP I), art. 11; Additional Protocol II (AP II), art. 5). In that respect, IHL prescribes obligations similar to those envisaged under human rights law.

When a state does not have full control over the detention of an individual, its ETOs will be graduated accordingly. For example, if US personnel interrogate a person detained in Afghanistan by Afghan authorities, the state's ETOs arise because interrogation constitutes a form of control over such person, particularly over the enjoyment of their rights (HRC 2018, para. 63). They also apply because of the control exercised by the state over its own agents, who in all circumstances must refrain from engaging in human rights violations (AComHPR 2015, para. 14; Milanovic 2011, pp. 209-210). Accordingly, in such circumstances, the US carries an obligation to respect the detainee's right to life and personal integrity, including by refraining from the use of torture and ill-treatment, in all circumstances.

On the other hand, it is more difficult to determine whether and to what extent the US' obligations to protect and fulfil would apply in such a scenario. One argument could be that, given the US exercises control over the detained individual through interrogation, albeit short of controlling other aspects of detention, it has an obligation to ensure that such a person is not detained arbitrarily by Afghan authorities, and that relevant procedural safeguards are in place. It is more difficult to clearly determine whether the act of interrogation alone is enough to establish that the US has 'effective control' over the detainee for purposes of proactively protecting and fulfilling the ESC rights of the detained individual. Not being the detaining authority, the US would not be directly responsible for securing all the ESC rights the detainee should be accorded, for instance in relation to food and clothing. The fact of the exercise of control through interrogation, however, may raise the question whether the US should ensure that Afghan authorities fulfil their obligations in respect of ESC rights as well, at least during the whole time the US personnel are involved in the detainee's questioning.

Against the background of the same factual scenario, a further question concerns whether the US bears ETOs vis-à-vis a person deprived of liberty when its personnel do not directly interrogate the latter. Certainly, if Afghan agents questioned a person under the direction of US personnel, these would be under an obligation not to engage in any prohibited conduct, such as torture or ill-treatment (Milanovic 2011, pp. 218-219). But what if US personnel witness acts of torture perpetrated by Afghan agents in their presence, without any involvement whatsoever? If the place of detention was under US control while torture is committed by Afghan agents, the US would have the obligation to protect the detainee, as the latter would fall under US' 
jurisdiction (Committee against Torture (CAT) 2008, para. 16). Yet, if this happens in a place under Afghan control, it can be questioned whether the US carries a legal obligation to prevent or stop such acts. One argument, to be tested, could be that, where US personnel have the ability or power to intervene and stop Afghan agents from torturing an individual, the US must do so as part of its obligation to respect under applicable human rights law.

\section{Occupation and other instances of effective control over territory}

ETOs also arise when 'as a consequence of military action - whether lawful or unlawful - [a state] exercises effective control of an area outside its national territory' (ECtHR 1995, para. 62). In this respect, ETOs derive 'from the fact of such control' (ECtHR 2011b, para. 138), giving rise to an obligation to guarantee the human rights of the people located in the area where effective control is exercised. As the HRC has affirmed, '... States parties must respect and protect the lives of individuals located in places, which are under their effective control, such as occupied territories' (2018, para. 63; also International Court of Justice (ICJ) 2004, paras. 109-110; 2005, paras. 178-180, 216-220). This is the so-called 'spatial model' of extraterritorial jurisdiction, according to which effective control over territory, possibly including just an 'area' or a 'place', functions as a threshold criterion that determines when a state has jurisdiction extraterritorially, and thus bears ETOs (Milanovic 2011, pp. $127 \mathrm{ff}$. and 210).

It is important to highlight that control over territory may vary across a spectrum of intensity. Examples range from full occupation of a territory followed by the displacement of local authorities (e.g., Russia's annexation of Crimea), to temporary control of a limited geographical area (such as a town, a building or even an apartment), to occupation without military presence on the ground (e.g., Israel's closure of the Gaza Strip). In such scenarios, states' ETOs will apply according to the type and degree of control exercised over the territory.

In situations of occupation, where a state exercises effective control over the occupied territory (ECtHR 2021a, para. 196), the degree of control exercised is particularly intense. In such a scenario, a state's ETOs are 'substantially similar to [the obligations] it assumes with regard to situations or persons in its national territory' (De Schutter et al. 2012, p. 1124). The ECtHR has ruled that an occupier is under an obligation to 'secure, within the area under its control, the entire range of substantive rights set out in the [European Convention on Human Rights ECHR] and those additional Protocols which it has ratified. It will be liable for any violations of those rights' (2011b, para. 138; also HRC 2014b and 2015). The CESCR has also affirmed that states must 'fully guarantee and implement the Covenant [ICESCR] rights for all persons in all territories under its effective control' (2011, para. 3). In addition, the Maastricht Principles provide that '[a] State in belligerent occupation or that otherwise exercises effective control over territory outside its national territory must respect, protect and fulfil the [ESC] rights of persons within that territory' (Principle 18). It follows that, in occupied territories, states bear the three obligations to respect, protect and fulfil the human rights of the local population, especially when local authorities have been displaced. Such a principle echoes what is prescribed under IHL, specifically the law of occupation, ${ }^{3}$ which derives from the 1907 Hague Regulations (HR), GC IV, AP I and related customary norms. Article $43 \mathrm{HR}$ prescribes that an occupier must 'take all the measures in his power to restore, and ensure, as far as possible public order and safety' which requires, inter alia, the maintenance of law enforcement in the occupied territory (Longobardo 2018, pp. $169 \mathrm{ff}$ ). This entails, for instance, a due diligence obligation to protect individuals from violence arising from private parties (ICJ 2005, paras. 178-180). The law of occupation also regulates the occupant's duties and responsibilities in relation to ESC rights (Giacca 2014). For instance, article 55 GC IV prescribes obligations in terms of "ensuring the food and medical 
supplies of the population', while article 69 AP I imposes an obligation to 'ensure the provision of clothing, bedding, means of shelter, other supplies essential to the survival of the civilian population of the occupied territory'.

Similar ETOs apply when occupied territory is unlawfully annexed (HRC 2015, para. 23; CESCR 2017a, paras. 9-10). The degree of control exercised in such instances is, in fact, equivalent if not more intense than during occupation, given annexation purports to appropriate foreign territory permanently. ${ }^{4}$ The ETOs relevant to situations of occupation also apply when territory is controlled by proxy. The ECtHR has found that a state has jurisdiction over foreign territory when, through a subordinate local administration, it exercises 'effective overall control' over such territory (1996, para. 56). In order to establish that such a test is met, it is not necessary to prove that the state "exercises detailed control over the policies and actions of the subordinate local administration', sufficing to establish that 'the local administration survives as a result of the Contracting State's military and other support' (2011b, para. 138). Accordingly, the controlling state must ensure the whole range of ETOs deriving from the human rights norms binding upon it (ibid). It is further worth highlighting that even military action resulting in the temporary exercise of effective control over a limited geographic area may trigger a state's jurisdiction under human rights law, making relevant ETOs applicable (ECtHR 2004, para. 74; Milanovic 2011, p. 138).

When control over territory is not as intense as in the aforementioned contexts, a state's ETOs will be graduated accordingly (De Schutter et al. 2012, p. 1108). A first scenario concerns occupied territories where local authorities retain some level of control, as in the case of Israel's occupation of the West Bank. The CESCR has specified that Israel 'has positive and negative obligations with regard to the Occupied Palestinian Territory, depending on its level of control and the transfer of authority' (2019, para. 11). In that regard, the occupier's primary obligation is to respect and not to interfere in the local authorities' fulfilment of those rights remaining under their competence (ICJ 2004, para. 112; also CESCR 2011, para. 8). As to the obligations to protect and fulfil, these are retained depending on the degree of control exercised. For instance, the occupier must provide the local population with access to drinking water or necessary healthcare, as prescribed under the ICESCR, to the extent local authorities cannot perform such duties because of the occupation. The occupier, on the other hand, will not be under the obligation to perform those tasks that can be fulfilled by local authorities. For instance, Israel does not have the duty to ensure law enforcement in those areas of the West Bank where such a task falls under the competence of the Palestinian Authority, whereas it retains law enforcement duties wherever the latter cannot exercise its powers. By way of example, Israel must protect Palestinians from threats or violence emanating from Israeli settlers in any area outside Palestinian Authority's control (HRC 2014b, para. 16).

A second scenario where a state's ETOs may be graduated is when effective control over territory is challenged, e.g., when the local population resists the occupation, especially by arms (e.g., as experienced by the United Kingdom (UK) in Iraq). If a state occupies a large area of another state's territory, but the local population still has full control of certain cities, then the occupier does not exercise 'effective control' over the latter for purposes of applying relevant ETOs - bar the obligation to respect, which applies in all circumstances. Limited to such areas, therefore, the occupier will not be under a duty to ensure law enforcement, or provide necessary services to ensure ESC rights. If the local population, on the other hand, is not in full control of certain areas but challenges the occupation through occasional armed actions, then a case-by-case assessment will determine what the occupier is required of in terms of the obligations to protect and fulfil, always in light of the degree of control exercised. A similar example regards situations in which fighting erupts to regain control over territory (e.g., Azerbaijan's 
military operations to retake Nagorno-Karabakh from Armenia). In such circumstances, ETOs will gradually cease to apply as the occupier loses effective control over territory, particularly in those areas from which it withdraws.

A third scenario concerns effective control over territory exercised without military presence on the ground. In the context of Israel's blockade and closure of the Gaza Strip, for instance, Israel exercises effective control over the land borders, maritime and air space of Gaza, in addition to maintaining its authority over the telecommunications, water, electricity and sewage networks and the population registry. This allows Israel to control all movements of people and goods in and out of Gaza, and to be capable of conducting military operations therein at will. Such conditions make Gaza an occupied territory in IHL terms (UN Human Rights Council (HRC) 2015, paras. 27-30), and amount to exercise of 'effective control' for purposes of ETOs applicability (HRC 2014b; CESCR 2019). In respect of the right to health, for example, barring Gazans from seeking medical treatment outside the Strip, or impeding the import of necessary medical equipment and supplies into Gaza, does not comport with Israel's obligation to respect such right. On the other hand, Israel is not directly responsible for running hospitals in Gaza, a duty that remains incumbent upon local authorities. However, Israel's exercise of control over electricity networks, on which the functioning of hospitals depends, imposes an obligation to provide an adequate amount of electricity, meaning Israel retains certain duties under the obligation to fulfil the right to health. In any case, determining which ETOs states bear when exercising effective control over territory without military presence on the ground requires a case-by-case evaluation in light of the concrete circumstances.

\section{Use of force by distance}

When force is used 'by distance', e.g., in absence of territorial control or physical control over a person, ETOs may derive from a state's ability to infringe upon human rights (Hampson 2008, p. 570; Milanovic 2011, pp. 209 ff.). With regard to the International Covenant on Civil and Political Rights (ICCPR), the HRC has affirmed that states must respect and ensure the right to life of:

all persons subject to its jurisdiction, that is, all persons over whose enjoyment of the right to life it exercises power or effective control. This includes persons located outside any territory effectively controlled by the state, whose right to life is nonetheless impacted by its military or other activities in a direct and reasonably foreseeable manner.

(2018, para. 63; also AComHPR 2015, para. 14)

In the HRC's view, the 'direct and reasonably foreseeable' impact on a person's right to life, as a form of exercise of 'power or effective control' over the enjoyment of such a right, is thus a condition that triggers ETOs under the ICCPR. This includes scenarios where force is used by distance without military presence on the ground, such as through airstrikes (HRC 2014c, para. 9(a)). It would also encompass situations where state armed forces are on the ground yet they do not have effective control over the territory in question, for instance during the invasion of a country, or the taking of a city under enemy control. In such contexts, states' ETOs will derive from the ability of its agents to have an impact on human rights.

It is worth noting that the ECtHR has not yet fully acknowledged that use of force by distance suffices to bring an individual under a state's jurisdiction (Joseph 2019, p. 349). In the Banković decision, the ECtHR affirmed that, absent effective control over foreign territory, use of force by distance is not sufficient to establish a jurisdictional link between a state and the 
targeted individual(s) (2001, para. 75). In the ECtHR's view, this would include the 'active phase of hostilities' of an international armed conflict, i.e. where 'armed confrontation and fighting between enemy military forces seeking to establish control over an area' take place (2021a, paras. 136-138). On the other hand, the ECtHR has at times acknowledged that use of force by distance may trigger ETOs under the ECHR (2007a, paras. 54-55; 2008, para. 51; 2011b, paras. 133-137).

When use of force has a nexus with an armed conflict, the protection of the right to life under human rights law intersects with the IHL rules on targeting. IHL imposes on the parties to a conflict to abide by, inter alia, the principles of distinction, proportionality and precautions in attack, under which lethal force may be used less restrictively than under human rights law (AP I, arts. 48, 51 and 57; AP II, art. 13). In this respect, the ICJ has affirmed that, to determine whether during the conduct of hostilities a deprivation of life is arbitrary, reference must be made to IHL rather than human rights norms (1996, para. 25; also AComHPR 2015, para. 32). In this respect, the HRC has stated that ' $\mathrm{u}] \mathrm{se}$ of lethal force consistent with international humanitarian law and other applicable international law norms is, in general, not arbitrary' (HRC 2018, para. 64). On the other hand, 'practices inconsistent with international humanitarian law, entailing a risk to the lives of civilians and other persons protected by international humanitarian law ... would also violate article 6 of the Covenant' (ibid; also AComHPR 2015, para. 32).

ETOs triggered by extraterritorial use of force extend to ESC rights as well. The Maastricht Principles provide that states bear ETOs in all situations where their acts 'bring about foreseeable effects on the enjoyment of [ESC] rights' (Principle 9(b)). Similarly, the CESCR has clarified that ' $[t]$ he extraterritorial obligation to respect requires states parties to refrain from interfering directly or indirectly with the enjoyment of the Covenant rights by persons outside their territories' (2017b, para. 29; also Maastricht Principles, Principle 20). Accordingly, a state has an obligation to respect ESC rights in the context of military action that may have 'foreseeable effects' on their enjoyment, e.g., in relation to the right to health when an airstrike targets a hospital. In this sense, a state must refrain from unlawfully interfering with any ESC right. It is to be noted that even the protection of ESC rights must take into consideration the co-applicability of IHL which, while prescribing less stringent rules on the targeting of objects, also imposes specific prohibitions regarding attacks that may infringe upon certain ESC rights (AP I, arts. 52-54; AP II, arts. 14, 16-17).

While states always have the obligation to respect the right to life and ESC rights, albeit in light of applicable IHL rules, use of force by distance will not trigger an obligation to protect. In fact, in order to protect a person's life or home from threats arising from private parties, states need to exercise effective control over a person or territory, namely a form and degree of control that allows, and requires, to perform such a task. The ability to 'impact' a person's rights may also not be, in itself, a sufficient condition to trigger the obligation to fulfil, as this requires implementing measures - e.g., providing adequate healthcare - a state is not in a position to give effect to, absent effective control over a territory or person.

\section{UN-mandated peace operations}

Peace operations are typically established by a United Nations Security Council's (UNSC) resolution, and may be led by the UN (e.g., the MINUSMA operation in Mali), other international organizations such as the North Atlantic Treaty Organization (e.g., the ISAF operation in Afghanistan), or a state. When participating in UN-mandated peace operations, states remain bound by their ETOs (Larsen 2012, p. 185). The HRC has affirmed that the ICCPR applies extraterritorially in respect of persons 'within the power or effective control of the forces [...] 
constituting a national contingent of a State Party assigned to an international peace-keeping or peace-enforcement operation' (2004a, para. 10; 2004b, para. 6; also CAT 2008, para. 16). As discussed above, what matters in this respect is the exercise of jurisdiction in the form of 'effective control' over a person or territory, as well as the 'direct and reasonably foreseeable' impact state action may have on a person's rights.

The ECtHR also found the ECHR to be applicable extraterritorially when states contribute troops to peace operations (2014b, para. 152; 2011a, paras. 85-86; 2015, para. 33). However, the ECtHR held that a state's obligations under the ECHR do not apply in relation to UNmandated peace operations when troops' conduct is attributable to the UN rather than the sending state. ${ }^{5}$ In the ECtHR's view, this situation arises when two conditions are fulfilled. First, the UNSC must 'delegate' part of its powers, which occurs when it empowers 'another entity to exercise its function as opposed to "authorising" an entity to carry out functions which it could not itself perform' (2007b, paras. 43, 128-131). Second, the UNSC must retain 'ultimate authority and control' over the peace operation, an assessment to be made on a case-by-case basis, inter alia in light of the operation's chain of command (ibid, paras. 133-134).

If such conditions are satisfied, the ECtHR deems the conduct of troops to be attributable to the UN and not to the sending state. This, in turn, excludes the applicability ratione personae of the ECHR, ${ }^{6}$ precluding a state's ETOs under this treaty from arising in the concrete circumstances. In subsequent case law, the ECtHR has applied this same principle, either reaching the same conclusions in terms of attribution of conduct (inter alia 2007 c, p. 3), or finding that troops' conduct remained attributable to the sending state for failure to establish that the UNSC had 'delegated' its powers and had retained 'ultimate authority and control' over the peace operation (inter alia 2011a, paras. 79-84). Notwithstanding its many critical aspects, such jurisprudence remains part of the lex lata within the ECHR (Larsen 2012, p. 164), yet it does not affect the applicability of ETOs in peace operations under different treaties. It is also worth noting that dual attribution, i.e., attribution of the same conduct to more than one entity, may be a possible legal avenue to ensure the applicability of the ECHR in UN-mandated peace operations (ECtHR 2011a, para. 80; Larsen 2012, pp. 151-156).

Besides states, in UN-mandated peace operations international organizations may bear human rights obligations as well. The necessary condition in this regard is that international organizations have legal personality (Larsen 2012, pp. 89-90), which makes them bound by international customary and treaty law (ICJ 1980, p. 37). However, given human rights treaties are generally not open for ratification or access to by international organizations, except for the Convention on the Rights of Persons with Disabilities, these will principally be bound by customary human rights law. In this respect, many human rights have attained customary status, including the rights to life and to liberty (AComHPR 2015, para. 14; HRC 2001, para. 11). In absence of authoritative statement on the matter, it is sensible arguing that international organizations will bear ETOs according to the same rules applicable to states, i.e., when exercising effective control over a person or territory or when their action may impact an individual's rights (Engdahl 2012, pp. 69-71).

\section{Extraterritorial military action and the Maastricht Principles}

Over time, the Maastricht Principles have demonstrated their persistent utility when it comes to determining the applicability of ETOs in extraterritorial military action. On the one hand, they have entrenched the interpretation developed by the ICJ and human rights bodies - the 'effective control over a person or territory' criterion - connecting it to the extraterritorial application of ESC rights. On the other hand, they have been forward-looking and expansive in relation to 
situations that might escape a rigid interpretation of the 'effective control' criterion, particularly in relation to extraterritorial military action where states have no presence on the ground.

With regard to deprivation of liberty, the Maastricht Principles confirmed the 'effective control' criterion previously employed by human rights bodies to determine when ETOs apply in this context (Principles 9(a) and 18). The adoption of the Maastricht Principles constituted an important step to entrench the interpretation that ETOs relating to ESC rights apply in relation to deprivation of liberty, a context where human rights jurisprudence had primarily considered the protection of civil rights such as the rights to personal liberty and to be free from torture and ill-treatment. Additionally, by spelling out that states must 'refrain from conduct which nullifies or impairs the enjoyment and exercise of [ESC] rights of persons outside their territories' (Principle 20), the Maastricht Principles are also capable of encompassing situations where a state does not have full control of a person's detention, yet has the ability to infringe upon a detainee's rights - such as when it interrogates a person detained by another state.

Moreover, the Maastricht Principles acknowledge that 'effective control' over territory triggers state jurisdiction under applicable human rights treaties, which in turn gives rise to the obligation to respect, protect and fulfil ESC rights (Principle 18). Particularly when the exercise of effective control amounts to occupation, states 'may be obliged to secure the entire range of substantive rights' (De Schutter et al. 2012, p. 1108). In this sense, the Maastricht Principles reflect the consolidated jurisprudence of the ICJ and human rights bodies on the applicability of ETOs in situations of occupation. Remarkably, by further making reference to situations where a state 'otherwise exercises effective control over territory', the Maastricht Principles fill possible gaps regarding ETOs applicability in instances where territorial control falls short of occupation (see also ECtHR 2021a, para. 196).

In the context of use of force by distance, the Maastricht Principles have been groundbreaking in recognizing that ETOs arise in 'situations over which State acts or omissions bring about foreseeable effects on the enjoyment of economic, social and cultural rights, whether within or outside its territory' (Principle 9(b)). At the time they were adopted, in 2011, the human rights bodies' interpretation that ETOs attach to the impact that state acts may have on human rights, besides the exercise of effective control over a person or territory, had not yet fully consolidated. This would later emerge in the General Comments of the AComHPR, which referred to 'conduct which could reasonably be foreseen to result in an unlawful deprivation of life' (2015, para. 14), and the HRC, which connected ETOs to the 'direct and reasonably foreseeable' impact of military or other activities on the right to life (2018, para. 63). While it goes beyond the scope of this contribution to enquire on whether such language directly draws on the Maastricht Principles, the latter have certainly anticipated the interpretive trend later adopted by human rights bodies. In this sense, they have constituted an important step in the expansion of the protection of human rights, including but not limited to ESC rights, in the context of extraterritorial military action.

\section{Outlook}

To conclude, it is pertinent to point out - without purporting to be exhaustive - some questions that are still in need of clarification and further research with regard to the application of ETOs in the context of extraterritorial military action. First, there are instances in which it remains unclear whether states bear ETOs at all. One example is that of state A's agents witnessing state B's officials torturing a detainee where state A has no control over the detained person or the area of detention. In that instance, what needs to be explored is whether, under human rights law, a state bears a due diligence obligation to prevent another state from committing a human rights violation, risking to incur responsibility for failure to fulfil such a duty. 
Second, in light of the constant resort to human rights mechanisms in order to seek justice for violations occurring in armed conflict, states might start adopting derogations when conducting extraterritorial military action. In this sense, it is yet to be tested to what extent derogations adopted in the context of extraterritorial military operations could comply with the strict requirements prescribed under human rights law (inter alia HRC 2001). For instance, how would conducting military operations abroad or contributing troops to UN-mandated peace operations amount to a 'public emergency which threatens the life of the nation', the necessary condition for states to resort to derogations under Article 4 ICCPR?

Third, when conducting extraterritorial military action states have a duty to investigate alleged human rights violations committed by their agents. The Minnesota Protocol on the Investigation of Potentially Unlawful Death provides that ' $[t]$ he duty to investigate applies wherever the state has a duty to respect, protect and/or fulfil the right to life, and in relation to any alleged victims or perpetrators within the territory of a state or otherwise subject to a state's jurisdiction' (OHCHR 2016, para. 19). Indeed, a corollary of states' obligation to respect human rights in extraterritorial contexts is that a duty to investigate arises whenever the former is breached, and the specific right violated - e.g., the right to life - calls for the opening of an investigation (Milanovic 2011, pp. 216-217). The ECtHR, for example, has considered the obligation to investigate in the context of extraterritorial military action (2011b, 2014b, 2021a, 2021b). While human rights bodies have clarified that states must carry out effective investigations in connection with extraterritorial military action, some questions remain open. For instance, to what extent should security concerns characterizing armed conflict be taken into account in the assessment of whether a state has fulfilled its duty to investigate in line with international standards (inter alia ECtHR 2014b, 2021b)? And how are states supposed to discharge the obligation to investigate when alleged human rights violations are committed in connection with use of force by distance, i.e., in relation to contexts where they have no presence on, and access to, the ground?

Fourth, questions exist with regard to the allocation of ETOs when states conduct military action in partnership with other states or international organizations. This concerns both the fulfilment of substantive obligations - who is responsible for securing which rights to the affected individuals - and the procedural duty to investigate. For instance, when conducting airstrikes, what ETOs does state A bear if its action is limited to the refuelling of aircrafts of state B, the one actually carrying out an attack? Do both states bear the same ETOs, or are these graduated in accordance with the role played by a state in a military operation? Who among such states bears the duty to investigate in case relevant human rights are violated? Or, what ETOs states have in respect of the transfer of arms to another state? Also, can a state be held responsible for complicity in human rights violations in any of these scenarios, and what are the scope and limits of state complicity in this respect?

While nowadays there is no doubt states bring their human rights obligations along when conducting extraterritorial military action, multiple legal challenges still remain. Future practice and research must test the unexplored terrains where human rights protection is at risk, attempting to find solutions that would prevent states from escaping their ETOs when acting militarily abroad.

\section{Notes}

1. IHL regulates the grounds for internment and relative procedural guarantees in respect of international armed conflicts only. It remains debated whether IHL also authorizes security detention in noninternational armed conflicts. For discussion, see Hill-Cawthorne (2016). 
2. This interpretive operation is based on Article 31(3)(c) of theVienna Convention on the Law of Treaties, or equivalent provisions included in certain human rights treaties, which requires, in the interpretation of a treaty, to take account of 'any relevant rules of international law applicable in the relations between the parties'. This is known as the principle of systemic integration, which human rights bodies resort to when dealing with the relationship between human rights law and IHL (Todeschini 2018).

3. According to Article $42 \mathrm{HR}$, '[t]erritory is considered occupied when it is actually placed under the authority of the hostile army'.

4. Annexation, when effected as forceful acquisition of territory, amounts to a prohibited use of force under Article 2(4) of the Charter of the United Nations. Importantly, annexed territory continues to be classified as occupied territory for purposes of IHL applicability; see GC IV, art. 47.

5. Attribution of conduct is concerned with linking the acts and omissions of a physical person to an abstract entity such as a state or an international organization.

6. A treaty's scope of application ratione personae circumscribes the subjects it applies to, which are the states parties to it.

\section{References}

African Commission on Human and Peoples' Rights (2015) GC 3 on the Right to Life (Article 4), 57th Ordinary Session.

Committee against Torture (CAT) (2008) GC 2 on Implementation of Article 2 by States Parties, CAT/C/ GC/2.

Committee on Economic, Social and Cultural Rights (CESCR) (1990) GC 3 on the Nature of States Parties' Obligations (art. 2, para. 1), E/1991/23.

(2000) GC 14 on the Right to the Highest Attainable Standard of Health (art. 12), E/C.12/2000/4.

(2011) Concluding Observations: Israel, E/C.12/ISR/CO/3.

(2017a) Concluding Observations: Russia, E/C.12/RUS/CO/6.

(2017b) GC 24 on State Obligations under the International Covenant on Economic, Social and

Cultural Rights in the Context of Business Activities, E/C.12/GC/24.

(2019) Concluding Observations: Israel, E/C.12/ISR/CO/4.

De Schutter, O. et al. (2012) 'Commentary to the Maastricht Principles on Extraterritorial Obligations of States in the Area of Economic, Social and Cultural Rights', Human Rights Quarterly 34, 1084-1169.

Engdahl, O. (2012) 'Applicability/Application of Human Rights Law to International Organisations Involved in Peace Operations', Proceedings of the 12th Bruges Colloquium.

European Court of Human Rights (ECtHR) (1995) Loizidou v. Turkey (Preliminary Objections), Application no: $15318 / 89$, Judgment.

(1996) Loizidou v. Turkey (Merits), Application no: 15318/89, Judgment.

(2001) Banković and others v. Belgium and Other 16 Contracting States, Application no: 52207/99,

Decision.

(2004) Issa and others v. Turkey, Application no: 31821/96, Judgment.

(2007a) Pad and others v. Turkey, Application no: 60167/00, Decision.

(2007b) Behrami and Behrami v. France, Application no: 71412/01, Decision and Saramati v. France,

Germany and Norway, Application no: 78166/01, Decision.

(2007c) Kasumaj v. Greece, Application no: 6974/05, Decision.

(2008) Solomou and others v. Turkey, Application no: 36832/97, Judgment.

(2011a) Al-Jedda v. The United Kingdom, Application no: 27021/08, Judgment.

(2011b) Al-Skeini and others v. The United Kingdom, Application no: 55721/07, Judgment.

(2014a) Hassan v. United Kingdom, Application no: 29750/09, Judgment.

(2014b) Jaloud v. The Netherlands, Application no: 47708/08, Judgment.

(2015) Pisari v. the Republic of Moldova and Russia, Application no: 42139/12, Judgment.

(2021a) Georgia v. Russia (II), Application no: 38263/08, Judgment.

(2021b) Hanan v. Germany, Application no: 4871/16, Judgment.

Giacca, G. (2014) Economic, Social, and Cultural Rights in Armed Conflict, Oxford University Press. 
Hampson, F. (2008) 'The Relationship between International Humanitarian Law and Human Rights Law from the Perspective of a Human Rights Treaty Body', International Review of the Red Cross 871, 549-572. Hill-Cawthorne, L. (2016) Detention in Non-International Armed Conflicts, Oxford University Press.

Inter-American Commission on Human Rights (1999) Coard et al. v. United States (Merits), Report no. 109/99.

International Court of Justice (ICJ) (1980) Interpretation of the Agreement of 25 March 1951 between the WHO and Egypt, Advisory Opinion.

(1996) Legality of the Threat or Use of Nuclear Weapons, Advisory Opinion.

(2004) Legal Consequences of the Construction of a Wall in the Occupied Palestinian Territory, Advisory Opinion.

(2005) Armed Activities on the Territory of the Congo (Democratic Republic of the Congo v. Uganda), Judgment.

Joseph, S. (2019) 'Extending the Right to Life under the International Covenant on Civil and Political Rights: General Comment 36', Human Rights Law Review 19, 347-368.

Larsen, K.M. (2012) The Human Rights Treaty Obligations of Peacekeepers, Cambridge University Press.

Longobardo, M. (2018) The Use of Armed Force in Occupied Territory, Cambridge University Press.

Milanovic, M. (2011) Extraterritorial Application of Human Rights Treaties. Law, Principles, and Policy, Oxford University Press.

Office of the High Commissioner for Human Rights (2016) The Minnesota Protocol on the Investigation of Potentially Unlawful Death.

Todeschini,V. (2018) 'The Impact of International Humanitarian Law on the Principle of Systemic Integration', Journal of Conflict and Security Law 23, 359-382.

UN Human Rights Committee (HRC) (2001) GC 29 on States of Emergency (Article 4), CCPR/C/21/ Rev.1/Add.11.

(2004a) GC 31 on the Nature of the General Legal Obligation on States Parties to the Covenant, CCPR/C/21/Rev.1/Add.13.

(2004b) Concluding Observations: Belgium, CCPR/CO/81/BEL.

(2014a) GC 35 on Article 9 (Liberty and Security of Person), CCPR/C/GC/35.

(2014b) Concluding Observations: Israel, CCPR/C/ISR/CO/4.

(2014c) Concluding Observations: United States of America, CCPR/C/USA/CO/4.

(2015) Concluding Observations: Russia, CCPR/C/RUS/CO/7.

(2018) GC 36 on Article 6 (The Right to Life), CCPR/C/GC/36.

UN Human Rights Council (2015) Report of the detailed findings of the independent commission of inquiry established pursuant to Human Rights Council resolution S-21/1,A/HRC/29/CRP.4. 